\title{
Development and quality of bovine embryos produced in vitro using growth factor supplemented serum-free system
}

\author{
Arindam Dhali, Vahida M. Anchamparuthy, Steve P. Butler, Isis K. Mullarky, Ronald E. Pear- \\ son, Frank C. Gwazdauskas*
}

Department of Dairy Science, Virginia Polytechnic Institute and State University, Blacksburg, USA;

Corresponding Author: guaz@,vt.edu

Received 1 July 2011; revised 10 August 2011; accepted 31 August 2011.

\begin{abstract}
The influence of a growth factor supplemented serum-free system on the development, gene expression, and cryotolerance of in vitro produced bovine embryos was investigated. To assess the embryo development and gene expression in blastocysts, abattoir-derived oocytes (obtained from $3-10$ or $<3 \mathrm{~mm}$ follicles) were matured and fertilized in serum-free media and cultured in synthetic oviductal fluid supplemented with fetal bovine serum (FBS, 4\%), epidermal growth factor (EGF, $10 \mathrm{ng} / \mathrm{mL}$ ), insulin like growth factor-1 (IGF-1, $100 \mathrm{ng} / \mathrm{mL}$ ), stem cell factor (SCF, $50 \mathrm{ng} / \mathrm{mL}$ ) or combinations of the growth factors. Expressions of selected gene transcripts were relatively quantified in the $\mathrm{d} 8$ blastocysts. To assess the cryotolerance, d 4 morulae (derived from $3-10 \mathrm{~mm}$ follicles and cultured with the supplementation of FBS or combinations of the growth factors) were vitrified, thawed and cultured (with respective supplementations). Total cell number and DNA fragmentation in blastocysts derived from the vitrified morulae were assessed through TUNEL assay. The rate (\%) of cleavage, blastocyst and expanded/hatched blastocyst did not differ among the culture medium supplementations within the follicle size of $3-10 \mathrm{~mm}$ (range $65.1 \pm$ $4.3-75.4 \pm 3.9 ; 22.4 \pm 3.9-36.4 \pm 3.6$; and $11.2 \pm$ $2.9-23.3 \pm 3.2$, respectively) or $<3 \mathrm{~mm}$ (range $59.3 \pm 4.2-74.5 \pm 3.7 ; 15.0 \pm 3.5-28.7 \pm 4.5$; and $9.3 \pm 2.8$ - $17.3 \pm 2.7$, respectively). Nevertheless, significantly lower $(P<0.05)$ cleavage and blastocyst rates with FBS and lower blastocyst rate with SCF supplementations were observed for the oocytes derived from $<3$ compared to 3 $10 \mathrm{~mm}$ follicles. The expression patterns of
\end{abstract}

$B C L-2, B A X, H S P 1 A 1, G J A 1$ and BIRC5 transcripts varied significantly $(P<0.05)$ in all cases, except for BIRC5 in the blastocysts derived from 3 - $10 \mathrm{~mm}$ follicles. Following thaw and culture, the development (\%) of vitrified morulae into expanded/hatched blastocysts was lower ( $P$ $<0.01$ ) with the supplementation of growth factors compared to FBS. In contrast, total number of cells and DNA fragmentation index in blastocysts were not different among the treatments. In conclusion, the growth factor supplemented serum-free system was satisfactory for in vitro bovine embryo production. Nevertheless, the system was not efficient when embryos were derived from $<3 \mathrm{~mm}$ follicles and cultured with SCF. Additionally, gene expression patterns and cryotolerance of the embryos were affected with the treatments of growth factors compared to serum.

Keywords: IVF; Growth Factors; Embryo Development; Gene Expression; Cryotolerance; Bovine

\section{INTRODUCTION}

Although the intrinsic quality of oocytes determines embryo quality, the microenvironment of the in vitro production system largely influences the development and quality of embryos [1-5]. A wide range of culture systems supports the in vitro development of preimplantation embryos [6]. Serum supplemented systems have been used widely for in vitro embryo production. Nevertheless, the composition of serum and its effects on embryo development are variable. A prolonged exposure to serum may alter embryo quality and affect fetal development [5]. A chemically defined serum-free system is advantageous for in vitro embryo production as exclu- 
sion of serum in the media avoids its negative influences on embryo development and quality [7]. Hence, the embryos produced in a serum-free system can serve as valuable model for many research applications.

Previous attempts have assessed the beneficial effects of growth factors on the development and quality of in vitro produced embryos. Insulin like growth factor-1 (IGF-1) improves the survival of embryos [8] and serves as an anti-apoptotic factor during bovine oocyte maturation and embryo development $[9,10]$. Moreover, IGF-1 protects preimplantation embryos against heat shock [11]. Epidermal growth factor (EGF) exerts a positive effect on blastocyst cell number, but it may not serve as an anti-apoptotic factor [9]. Stem cell factor (SCF) enhances the development of embryos into late blastocyst and hatching stages [12] and improves the quality of embryos cultured with $500 \mathrm{ng} / \mathrm{mL}$ Fas-L [13]. It is evident that IGF-1, EGF and SCF protect embryos from oxidative stress [14].

In vitro produced embryos are exposed to sub-optimal conditions that greatly differ from the in vivo environment. The composition of culture medium mimicking the in vivo environment including growth factors is crucial to enhance embryo development in vitro [15]. The development and quality of synthetic oviductal fluid (SOF) generated embryos are more similar to those of in vivo embryos than are those embryos produced in tissue culture medium 199 (TCM 199) [2]. The efficiency of an in vitro embryo production system is traditionally assessed on the basis of cleavage of fertilized oocytes and their further development into blastocysts. Nevertheless, a simultaneous assessment of embryo quality would be advantageous for understanding the influence of the microenvironment of such a system. Cryotolerance and the expression pattern of development and apoptosis related genes are useful indicators of the quality of embryos produced in vitro $[5,6]$.

Currently, insufficient information is available on the effect of growth factor supplemented serum-free systems on the development and quality of in vitro produced bovine embryos. In this study, we assessed the influence of serum-free IVM and IVF, and growth factor (IGF-1, EGF, SCF) supplemented serum-free IVC on the development, gene expression, and cryotolerance of bovine embryos.

\section{MATERIALS AND METHODS}

The chemicals used in the experiments were procured from Mallinckrodt Baker Inc., Phillipsburg, NJ, USA unless mentioned otherwise. The growth factors (IGF-1, EGF, SCF), essential amino acids solution, non essential amino acids solution, TCM 199 and gentamicin sulfate solution were procured from Invitrogen Corporation,
Carslbad, CA, USA. Fetal bovine serum (FBS), bovine serum albumin (BSA, fraction $\mathrm{V}$, fatty acid free), $\mathrm{FSH}$, LH, 17 $\beta$-estradiol, sodium pyruvate, L-glutamine, heaprin, and phenol red solution were procured from SigmaAldrich, St. Louis, MO, USA. The same BSA brand was used for performing IVM, IVF and IVC during the study.

\subsection{Design of Experiment}

\subsubsection{Experiment-1}

In this experiment, the effect of growth factor supplemented serum-free system on the development and gene expression of in vitro produced bovine embryos was assessed. Oocytes were aspirated from 3 - 10 or $<3$ $\mathrm{mm}$ follicles and matured and fertilized in serum-free media. Presumptive zygotes were cultured in growth factor supplemented serum-free medium. The development of embryos was recorded during the culture period and expressions of the development and apoptosis related gene transcripts were relatively quantified in the $\mathrm{d}$ 8 blastocysts. The oocytes were grouped on the basis of their follicle size as low developmental competence is evident for the bovine oocytes derived from $<3 \mathrm{~mm}$ follicles $[16,17]$.

\subsubsection{Experiment-2}

In this experiment, cryotolerance and apoptosis of the morulae produced in vitro using the growth factor supplemented serum-free system were assessed. Oocytes were aspirated from 3 - $10 \mathrm{~mm}$ follicles, matured, fertileized, and cultured as mentioned above. Morulae were vitrified, thawed, and cultured and the post-thaw development and apoptosis in the embryos were assessed.

\subsection{In Vitro Embryo Production}

Previously we have reported the detailed procedures of in vitro bovine embryo production using a serum-free SOF based system [18]. In brief, oocytes were aspirated from 3-10 or $<3 \mathrm{~mm}$ follicles of abattoir-derived ovaries. IVM of the oocytes was conducted for 22 to $24 \mathrm{~h}$ in TCM 199 supplemented with BSA $(8 \mathrm{mg} / \mathrm{mL}), \mathrm{LH}(0.02$ $\mathrm{U} / \mathrm{mL}), \mathrm{FSH}(0.02 \mathrm{U} / \mathrm{mL})$ and $17 \beta$-estradiol $(1 \mu \mathrm{g} / \mathrm{mL})$. Sperm samples (provided by two bulls) were prepared for IVF through the swim-up separation method in heaprin $(10 \mu \mathrm{g} / \mathrm{mL})$ and BSA $(8 \mathrm{mg} / \mathrm{mL})$ supplemented HEPES buffered SOF-IVF medium. Matured oocytes were washed and placed into $48 \mu \mathrm{L}$ drops (10 oocytes/drop) of heparin and BSA supplemented SOF-IVF under mineral oil. A prepared sperm sample $(2 \mu \mathrm{L})$ was added into each drop for a final volume of $50 \mu \mathrm{L}$ and concentration of $1 \times 10^{6} \mathrm{sperm} / \mathrm{mL}$. Cumulus cells were removed from the oocytes after an $18 \mathrm{~h}$ of sperm-oocyte 
incubation and presumptive zygotes were cultured in the drops of SOF-IVC medium supplemented with BSA ( 8 $\mathrm{mg} / \mathrm{mL}$, in all experimental groups) and FBS (4\%), IGF-1 (100 ng/mL), EGF (10 ng/mL), SCF (50 ng/mL), $\mathrm{EGF}(10 \mathrm{ng} / \mathrm{mL})+\mathrm{IGF}-1(100 \mathrm{ng} / \mathrm{mL}), \mathrm{EGF}(10 \mathrm{ng} / \mathrm{mL})$ + SCF $(50 \mathrm{ng} / \mathrm{mL})$ or IGF-1 (100 ng/mL) + SCF $(50$ $\mathrm{ng} / \mathrm{mL}$ ). During IVM, IVF and IVC, the oocytes or embryos were incubated in a humidified $5 \% \mathrm{CO}_{2}$ atmosphere at $38.5^{\circ} \mathrm{C}$. The development of embryos was recorded on $\mathrm{d} 4(\sim 114 \mathrm{~h}$ post-insemination) and $\mathrm{d} 8(\sim 210$ $\mathrm{h}$ post-insemination) of IVC.

\subsection{Quantitative Real-Time PCR Analysis}

The expression of development and apoptosis related gene transcripts in blastocysts was relatively quantified by reverse transcription and real-time quantitative PCR methods. In brief, d 8 blastocysts $(\sim 210 \mathrm{~h}$ post-insemination) were collected, washed in Dulbeccos PBS (Invitrogen Corporation) supplemented with $0.1 \%$ polyvinyl alcohol and stored in pools at $-80^{\circ} \mathrm{C}$ until processed for RNA extraction. Total RNA was extracted from blastocysts using Absolutely RNA ${ }^{\circledR}$ Microprep Kit (Stratagene, La Jolla, CA, USA). Purified RNA was transcribed into cDNA immediately using High-Capacity cDNA Archive Kit (Applied Biosystems, Foster City, CA, USA) and stored at $-20^{\circ} \mathrm{C}$ until used for PCR analysis.

Real-time PCR was performed in a 7300 Real-Time PCR System (Applied Biosystems) using SYBR ${ }^{\circledR}$ Green detection protocol. Briefly, cDNA (equivalent to $4 \mathrm{ng}$ of total RNA), $0.2 \mu \mathrm{M}$ of each primer and $1 \times \mathrm{SYBR}^{\circledR}$ Green Mix (Applied Biosystems) were used in a total volume of $25 \mu \mathrm{L}$. When the reaction was completed, melting curve analysis was performed to confirm the product purity. Specific primers were designed and used to amplify ACTB ( $\beta$-actin) (sense 5'-CTCTTCCAG CCTTCCTTCCT-3' and antisense 5'-GGGCAGTGA Tctctttctgc-3', 178 bp amplicon), BAX (sense 5'-TCTGACGGCAACTTCAACTG-3' and antisense 5'-TGGGTGTCCCAAAGTAGGAG-3', 205 bp amplicon), BCL-2 (sense 5'-ATGACTTCTCTCGGCGCTAC3' and antisense 5'-CGGTTCAGGTACTCGGTCAT-3', 244 bp amplicon), HSPA1A (heat shock protein 70) (sense 5'-CAAGATCACCATCACCAACG-3' and antisense 5'-AAATCACCTCCTGGCACTTG-3', 239 bp amplicon), GJA1 (connexin 43) (sense 5'-GGACATGCACTTGAAGCAGA-3' and antisense 5'-TGTAAACGGCACTCAAGCTG-3', 188 bp amplicon) and BIRC5 (survivin) (sense 5'-CCTGGCAGCTCTACCTCAAG-3' and antisense 5'-GAAAGCACAACCGGATGAAT-3', 233 bp amplicon), The relative abundance of gene transcripts was calculated using the $2^{-\Delta \Delta \mathrm{Ct}}$ method and $\beta$-actin as endogenous reference gene $[6,19]$.

\subsection{Vitrification, Thawing and Culturing of Embryos}

Morulae were produced in vitro from the oocytes aspirated from 3 - $10 \mathrm{~mm}$ follicles. Oocytes were matured, fertilized, and presumptive zygotes were cultured for $4 \mathrm{~d}$ in the drops of SOF-IVC medium supplemented with BSA ( $8 \mathrm{mg} / \mathrm{mL}$, in all experimental groups) and FBS (4\%), EGF (10 ng/mL)+IGF-1 (100 ng/mL), EGF (10 $\mathrm{ng} / \mathrm{mL})+\mathrm{SCF}(50 \mathrm{ng} / \mathrm{mL})$ or IGF-1 $(100 \mathrm{ng} / \mathrm{mL})+\mathrm{SCF}$ (50 ng/mL). The d 4 ( $114 \mathrm{~h}$ post-insemination) morulae were vitrified using the modified droplet vitrification method described previously [19]. Composition of the vitrification solution (VS) was $17.5 \%$ ethylene glycol, $17.5 \%$ dimethyl sulfoxide, $0.5 \mathrm{M}$ sucrose and $4 \mathrm{mg} / \mathrm{mL}$ BSA in TCM-199 medium. Briefly, 6 to 8 embryos were equilibrated in the equilibration medium $(50 \% \mathrm{VS}$ in TCM-199) for $3 \mathrm{~min}$ and subsequently washed in VS three times. The embryos along with VS were aspirated into a pipette. The pipette was held horizontally and a drop $(\sim 5 \mu \mathrm{L})$ containing embryos in VS was formed at the tip. The pipette was then held at $45^{\circ}$ above the liquid nitrogen level $(\sim 5 \mathrm{~cm})$ and the drop was placed onto liquid nitrogen by applying a gentle tweak and liquid nitrogen was poured over the drop. The drop was vitrified and sank into liquid nitrogen immediately. The interval between the contact of embryos with VS and cooling did not exceed $45 \mathrm{~s}$. Thawing and removal of cryoprotectants were done by placing the vitrified drop directly into dilution medium $(0.3 \mathrm{M}$ sucrose and $4 \mathrm{mg} / \mathrm{mL}$ BSA in TCM-199 medium) for $3 \mathrm{~min}$ and then transfer into SOF-IVC medium for $5 \mathrm{~min}$. Morphologically normal embryos were subsequently washed in SOF-IVC medium and cultured for $4 \mathrm{~d}$ in the drops of SOF-IVC supplemented with BSA and FBS or respective growth factors as stated previously. A morula was considered to have survived following vitrification and thawing when it cleaved further during the post-thaw culturing $(\sim 24 \mathrm{~h}$ post-thaw). Development of vitrified morulae into blastocysts or expanded/hatched blastocysts was recorded at the end of culturing ( $\sim 96 \mathrm{~h}$ post-thaw).

\subsection{Detection of DNA Fragmentation by TUNEL Assay}

The TUNEL assay was performed using the In Situ Cell Death Detection Kit (Fluorescein; Roche Diagnostics Corp., Indianapolis, IN, USA) according to the method described previously [20] after suitable modifycations. Embryos were stained on microscopic slides and washed in SOFH-IVF during the procedure. Briefly, blastocysts derived from the vitrified morulae were washed four times and fixed in paraformaldehyde solution $(4 \% \mathrm{w} / \mathrm{v}$ in PBS, $\mathrm{pH} 7.4)$ for $1 \mathrm{~h}$ at room tempera- 
ture. Embryos were washed and incubated in permeabilization solution $[0.5 \%(\mathrm{v} / \mathrm{v})$ Triton X-100, $0.1 \%(\mathrm{w} / \mathrm{v})$ sodium citrate] for $30 \mathrm{~min}$ at room temperature. After washing, positive and negative control embryos were incubated in DNase $(50 \mathrm{U} / \mathrm{mL})$ at $37^{\circ} \mathrm{C}$ for $20 \mathrm{~min}$. Embryos were washed and the treatment and positive control embryos were incubated in TUNEL reaction mixture in the dark for $1 \mathrm{~h}$ at $37^{\circ} \mathrm{C}$ in a humidified chamber. The negative control embryos were incubated in the absence of the enzyme terminal transferase. Following the TUNEL reaction, the embryos were washed and incubated in RNase A $(50 \mu \mathrm{g} / \mathrm{mL})$ for $1 \mathrm{~h}$ at room temperature in the dark. Embryos were incubated in propidium iodide $(0.5$ $\mu \mathrm{g} / \mathrm{mL}$; Roche Diagnostics Corp.) for $30 \mathrm{~min}$ at room temperature in the dark to label all nuclei. The embryos were washed to remove excess propidium iodide and a cover slip was mounted over the samples. The stained embryos were examined under a Zeiss LSM 510 laser scanning microscope. Positive reactivity was indicated by a bright green/yellow fluorescence indicating cells with DNA fragmentation and the total cell number was determined by red fluorescence. The DNA fragmentation index was calculated by dividing the number of TUNELpositive cells by the total number of cells per embryo.

\subsection{Statistical Analysis}

Data were analyzed using the SPSS 14.0 software package (SPSS Inc., Chicago, Illinois, USA) and presented as mean \pm SEM. In the Experiment-1, variations in the occurrence of different development stages were analyzed among treatments (IVC medium supplementation) for each follicle size ( $3-10$ or $<3 \mathrm{~mm}$ ) separately. Each embryo was assigned a score of either 1 (embryo developed into the stage of interest) or 0 (embryo did not develop into the stage of interest) and subjected to ANOVA followed by multiple pairwise mean comparesons using Student-Newman-Keuls (SNK) test [18]. In addition, variations in the occurrence of different development stages were analyzed between the follicle sizes for each IVC medium supplementation separately. Each embryo was given a score as stated above and subjected to ANOVA. Variations in the expression of different gene transcripts were analyzed by Student's t-test. In the Experiment-2, variations in the post-thaw development of vitrified embryos were analyzed among treatments (IVC medium supplementation). Each embryo was given a score as stated above and subjected to ANOVA followed by multiple pairwise mean comparisons using SNK test. Variations in the DNA fragmentation index and total number of cells in the TUNEL-stained embryos were analyzed among treatments (IVC medium supplementation) by ANOVA followed by multiple pairwise mean comparisons using SNK test.

\section{RESULTS}

\subsection{In Vitro Embryo Development}

The experiment was performed in three replicates to assess the effect of growth factor supplemented serumfree system on embryo development (Table 1). The rates of cleavage, morula, blastocyst and expanded/ hatched blastocyst development did not differ among the IVC medium supplementations within a follicle size (3 - 10 or $<3 \mathrm{~mm}$ ). Nevertheless, comparisons of embryo development between the follicle sizes for each IVC medium supplementation revealed lower $(\mathrm{P}<0.05)$ cleavage and blastocyst rates with FBS and blastocyst rate with SCF supplementations for the oocytes derived from $<3$ compared to $3-10$ follicles.

\subsection{Expression of Development and Apoptosis Related Gene Transcripts}

Three replicate PCR experiments were conducted to relatively quantify the expression of all genes. Total RNA was purified from 15 to 20 blastocysts from the three experimental pools for each treatment. The expression of different gene transcripts in the $\mathrm{d} 8$ blastocysts cultured with growth factor supplementations is depicted relative to that of the embryos cultured with FBS (Figure 1). $B C L-2$ expression was increased $(\mathrm{P}<0.05)$ with EGF, IGF-1 and EGF + IGF-1 treatments for $3-10 \mathrm{~mm}$ follicles and IGF-1, EGF + SCF and IGF-1 + SCF treatments for $<3 \mathrm{~mm}$ follicles. BAX expression was increased $(\mathrm{P}<0.05)$ when embryos were treated with growth factors irrespective of follicle size except for $<3$ $\mathrm{mm}$ follicles and EGF + IGF-1 treatment. Greater $(\mathrm{P}<$ 0.05) HSPA1A expression was observed in the embryos derived from 3 - $10 \mathrm{~mm}$ follicles with EGF + IGF-1 supplementation or $<3 \mathrm{~mm}$ follicles with EGF supplementation. The expression of GJA1 was $(\mathrm{P}<0.05)$ low when embryos were treated with growth factors irrespective of follicle size except for $3-10 \mathrm{~mm}$ follicles and IGF-1 treatment. Although similar BIRC5 expression was observed in the embryos derived from $3-10 \mathrm{~mm}$ follicles with growth factor treatments, it was less $(\mathrm{P}<0.05)$ in the embryos derived from $<3 \mathrm{~mm}$ follicles with EGF, $\mathrm{EGF}+\mathrm{SCF}$ and IGF-1 + SCF treatments.

\subsection{Development and Apoptosis of Embryos Following Vitrification, Thawing and Culturing}

The experiment was performed in six replicates to assess the development of vitrified morulae in different treatment groups (Table 2). Embryo development in all the vitrified groups was less $(\mathrm{P}<0.01)$ compared with that of non vitrified controls. Among the vitrified groups, 
Table 1. In vitro development (mean \pm SEM) of bovine embryos. Oocytes were aspirated from $3-10$ or $<3$ mm follicles, matured and fertilized in serum-free media and embryos were cultured in serum (FBS, 4\%) or growth factor (EGF, $10 \mathrm{ng} / \mathrm{mL}$; IGF-1, 100 $\mathrm{ng} / \mathrm{mL}$; SCF, $50 \mathrm{ng} / \mathrm{mL}$ ) supplemented medium.

\begin{tabular}{|c|c|c|c|c|c|}
\hline Experimental group & Oocytes fertilized (n) & Cleavage $(\%)$ & Morulae (\%) & Blastocysts (\%) & Expanded/hatched blastocysts (\%) \\
\hline \multicolumn{6}{|l|}{ 3-10 mm follicles } \\
\hline FBS & 176 & $73.9 \pm 3.3^{*}$ & $51.1 \pm 3.8$ & $36.4 \pm 3.6^{\S}$ & $23.3 \pm 3.2$ \\
\hline EGF & 116 & $71.6 \pm 4.2$ & $28.5 \pm 4.2$ & $22.4 \pm 3.9$ & $11.2 \pm 2.9$ \\
\hline IGF-1 & 137 & $74.5 \pm 3.7$ & $48.2 \pm 4.3$ & $28.5 \pm 3.9$ & $16.1 \pm 3.1$ \\
\hline $\mathrm{SCF}$ & 111 & $69.4 \pm 4.4$ & $33.3 \pm 4.5$ & $26.1 \pm 4.2^{\$}$ & $14.4 \pm 3.3$ \\
\hline EGF+IGF-1 & 139 & $74.8 \pm 3.7$ & $46.0 \pm 4.2$ & $34.5 \pm 4.0$ & $20.9 \pm 3.5$ \\
\hline $\mathrm{EGF}+\mathrm{SCF}$ & 122 & $75.4 \pm 3.9$ & $42.6 \pm 4.5$ & $24.6 \pm 3.9$ & $15.6 \pm 3.3$ \\
\hline $\mathrm{IGF}-1+\mathrm{SCF}$ & 126 & $65.1 \pm 4.3$ & $44.4 \pm 4.4$ & $27.8 \pm 4.0$ & $16.7 \pm 3.3$ \\
\hline \multicolumn{6}{|l|}{$<3 \mathrm{~mm}$ follicles } \\
\hline FBS & 202 & $64.4 \pm 3.4^{*}$ & $41.1 \pm 3.5$ & $26.2 \pm 3.1^{\S}$ & $17.3 \pm 2.7$ \\
\hline EGF & 101 & $68.3 \pm 4.7$ & $28.7 \pm 4.5$ & $28.7 \pm 4.5$ & $16.8 \pm 3.7$ \\
\hline IGF-1 & 123 & $71.5 \pm 4.1$ & $40.7 \pm 4.4$ & $22.8 \pm 3.8$ & $16.3 \pm 3.3$ \\
\hline SCF & 107 & $59.8 \pm 4.8$ & $23.4 \pm 4.1$ & $15.0 \pm 3.5^{\S}$ & $9.3 \pm 2.8$ \\
\hline EGF+IGF-1 & 130 & $70.8 \pm 4.0$ & $39.2 \pm 4.3$ & $25.4 \pm 3.8$ & $14.6 \pm 3.1$ \\
\hline $\mathrm{EGF}+\mathrm{SCF}$ & 137 & $74.5 \pm 3.7$ & $32.1 \pm 4.0$ & $27.7 \pm 3.8$ & $16.8 \pm 3.2$ \\
\hline IGF-1+SCF & 140 & $59.3 \pm 4.2$ & $35.0 \pm 4.0$ & $19.3 \pm 3.3$ & $12.1 \pm 2.8$ \\
\hline
\end{tabular}

${ }^{*, \S, \$}$ indicates that for the same symbol values differ significantly $(\mathrm{P}<0.05)$ between the follicle sizes for the given culture medium supplementation; Effect of treatments was not significant within the groups ( $3-10$ or $<3 \mathrm{~mm}$ follicles).
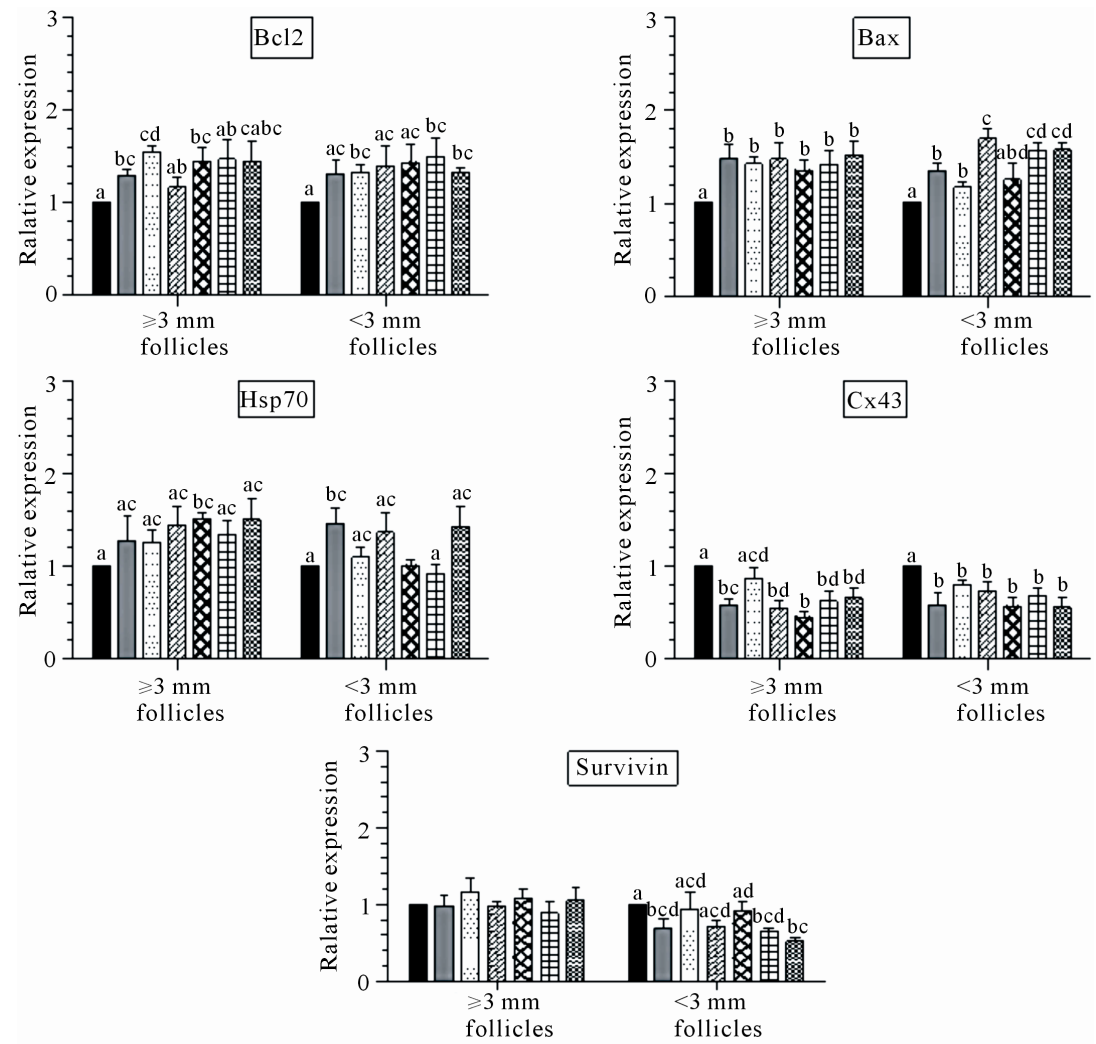

SBD 2 EGF $\cdots \mathrm{IGF}-1$-...

Figure 1. Variations (mean $\pm \mathrm{SEM}$ ) in the relative expression of BAX, BCL2, HSPA1A (Hsp70), GJA1 (connexin - Cx43) and BIRC5 (survivin) transcripts in the $\mathrm{d} 8$ bovine blastocysts produced in vitro. Oocytes were aspirated from $3-10$ or $<3 \mathrm{~mm}$ follicles, matured and fertilized in serum-free media and embryos were cultured in serum (FBS, 4\%) or growth factor (EGF, $10 \mathrm{ng} / \mathrm{mL}$; IGF-1, 100 $\mathrm{ng} / \mathrm{mL}$; SCF, $50 \mathrm{ng} / \mathrm{mL})$ supplemented medium. a-d on error bar indicates a significant difference $(\mathrm{P}<0.05)$. 
Table 2. Cryotolerance of bovine morulae produced in vitro. Oocytes were aspirated from 3-10 mm follicles, matured and fertilized in serum-free media and embryos were cultured in serum (FBS, 4\%) or growth factor (EGF, $10 \mathrm{ng} / \mathrm{mL}$; IGF-1, $100 \mathrm{ng} / \mathrm{mL}$; SCF, 50 $\mathrm{ng} / \mathrm{mL}$ ) supplemented medium. Day-4 morulae were vitrified and post-thaw culturing was done for $4 \mathrm{~d}$.

\begin{tabular}{|c|c|c|c|c|c|c|c|}
\hline Treatment & $\begin{array}{c}\text { Morulae } \\
\text { vitrified (n) }\end{array}$ & $\begin{array}{l}\text { Morulae } \\
\text { recovered after } \\
\text { thawing }(\mathrm{n})\end{array}$ & $\begin{array}{l}\text { Damaged } \\
\text { Morulae after } \\
\text { thawing (n) }\end{array}$ & $\begin{array}{l}\text { Morulae } \\
\text { cultured } \\
\text { (n) }\end{array}$ & $\begin{array}{l}\text { Morulae } \\
\text { survived } \\
(\% \pm \text { SEM })\end{array}$ & $\begin{array}{l}\text { Blastocysts } \\
(\% \pm \text { SEM })\end{array}$ & $\begin{array}{c}\text { Expanded/hatched } \\
\text { blastocysts } \\
(\% \pm \text { SEM })\end{array}$ \\
\hline \multicolumn{8}{|c|}{ Not vitrified control } \\
\hline FBS & - & - & - & 96 & $90.6 \pm 3.0^{\mathrm{A}}$ & $60.4 \pm 5.0^{\mathrm{A}}$ & $44.8 \pm 5.1^{\mathrm{A}}$ \\
\hline \multicolumn{8}{|l|}{ Vitrified } \\
\hline FBS & 109 & 106 & 3 & 103 & $75.7 \pm 4.2^{\mathrm{B}}$ & $44.7 \pm 4.9^{\mathrm{B}}$ & $28.2 \pm 4.5^{\mathrm{B}}$ \\
\hline $\mathrm{EGF}+\mathrm{IGF}-1$ & 110 & 109 & 7 & 102 & $67.0 \pm 4.7^{\mathrm{BC}}$ & $33.0 \pm 4.7^{\mathrm{BC}}$ & $15.5 \pm 3.6^{\mathrm{C}}$ \\
\hline $\mathrm{EGF}+\mathrm{SCF}$ & 110 & 108 & 6 & 102 & $57.3 \pm 4.9^{\mathrm{C}}$ & $29.1 \pm 4.5^{\mathrm{C}}$ & $12.6 \pm 3.3^{\mathrm{C}}$ \\
\hline IGF-1 + SCF & 111 & 109 & 6 & 103 & $61.2 \pm 4.8^{\mathrm{BC}}$ & $22.3 \pm 4.1^{\mathrm{C}}$ & $9.7 \pm 2.9^{\mathrm{C}}$ \\
\hline
\end{tabular}

$\overline{A, B, C}$ indicates values within column differ at $\mathrm{P}<0.01$.

following thaw and culture, lower $(\mathrm{P}<0.01)$ embryo survival with $\mathrm{EGF}+\mathrm{SCF}$ and blastocyst rate with EGF + SCF and IGF-1+SCF supplementations were observed compared to FBS. The development rate of expanded/hatched blastocyst was lower $(\mathrm{P}<0.01)$ with growth factor supplementations compared to FBS. To determine the total number of cells and DNA fragmentation in blastocysts, five embryos in each treatment group were subjected to TUNEL assay. Total number of cells was greater $(\mathrm{P}<0.05)$ in the non vitrified control group, but it was similar among the vitrified groups (Figure 2). Similarly, the DNA fragmentation index was lowest $(\mathrm{P}<$ 0.05 ) in the non vitrified control group, but it was not different among the vitrified groups (Figure 2).

\section{DISCUSSION}

The results indicated that the described growth factor supplemented serum-free system was satisfactory for in vitro bovine embryo production. Nevertheless, the system was not efficient when embryos were derived from $<3 \mathrm{~mm}$ follicles and cultured with SCF supplementation. Additionally, gene expression and cryotolerance of the embryos were affected with the treatments of growth factors compared to serum.

In the present study, oocytes were obtained from 3 10 or $<3 \mathrm{~mm}$ follicles, matured and fertilized in serumfree media and subsequently cultured in serum or growth factor supplemented medium. It is generally concluded that oocytes from larger follicles have a greater development competence than oocytes from smaller follicles [21]. Rate of normal fertilization is lower for the oocytes derived from 1 - 2 compared to 2 - 4 or 4 - $8 \mathrm{~mm}$ follicles [22]. Blastocyst yield is lower for the oocytes derived from $2-6$ than $>6 \mathrm{~mm}$ follicles [23]. Oocytes from $\leq 3 \mathrm{~mm}$ follicles either do not develop past the 16-cell stage [16] or yield fewer blastocysts compared to oocytes from $>3 \mathrm{~mm}$ follicles [17]. In our study, within a follicle size ( $3-10$ or $<3 \mathrm{~mm}$ ), similar embryo development was ob- served irrespective of culture medium supplementation. The results indicated that the described growth factor supplemented serum-free system was satisfactory for in vitro bovine embryo production using 3 $10 \mathrm{~mm}$ follicles. The comparisons of embryo development between the follicle sizes within a culture medium supplementation revealed similar embryo development irrespective of follicle size for all the supplementations except FBS and SCF. The development was significantly lower with FBS (cleavage and blastocyst) and SCF (blastocyst) supplementations when embryos were derived from $<3$ compared to $3-10 \mathrm{~mm}$ follicles. The results indicated that FBS and SCF supplementations were not efficient for embryo production from the oocytes derived from $<3 \mathrm{~mm}$ follicles, while similar blastocyst and expanded/hatched blastocyst rates irrespective of the source of oocytes were seen in our previous study [18].

The expression pattern of development and/or apoptosis related genes reflects embryo quality [2,24,25]. BIRC5 (survivin) is important for optimal embryo development and it suppresses apoptosis in preimplantation embryos [25]. Although HSPA1A is a constitutive gene in embryos, its expression level is linked to the response to cellular stress [26]. It is believed that the relative ratio between proapoptotic $(B A X)$ and antiapoptotic $(B C L-2)$ proteins determines the fate of blastomeres [27], but these proteins also function independently to regulate cell death [28]. GJA1 (connexin 43) expresses in preimplantation embryos and involves in cell compaction [6] and development [29]. In the current study, the expression of these gene transcripts was relatively quantified in the $\mathrm{d} 8$ blastocysts derived from $3-10$ or $<3 \mathrm{~mm}$ follicles and cultured with serum or growth factor supple- 


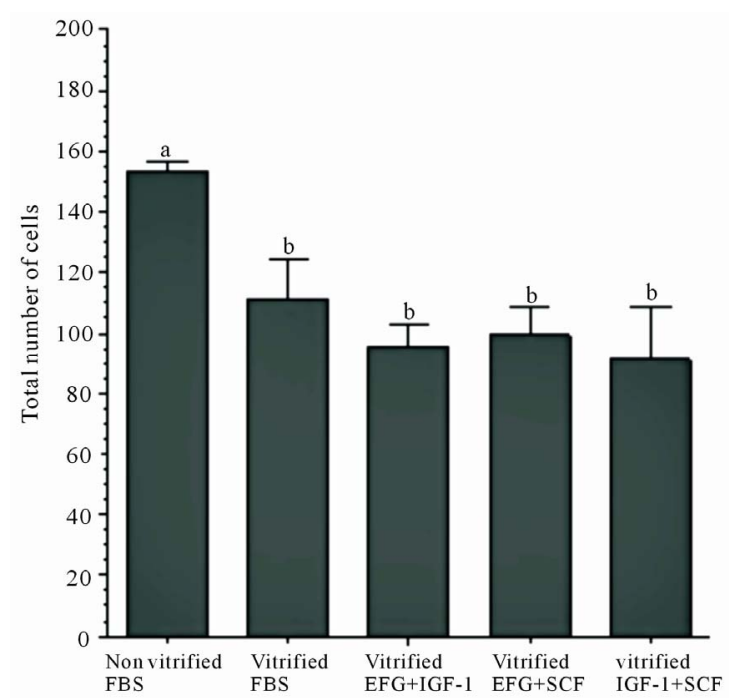

(a)

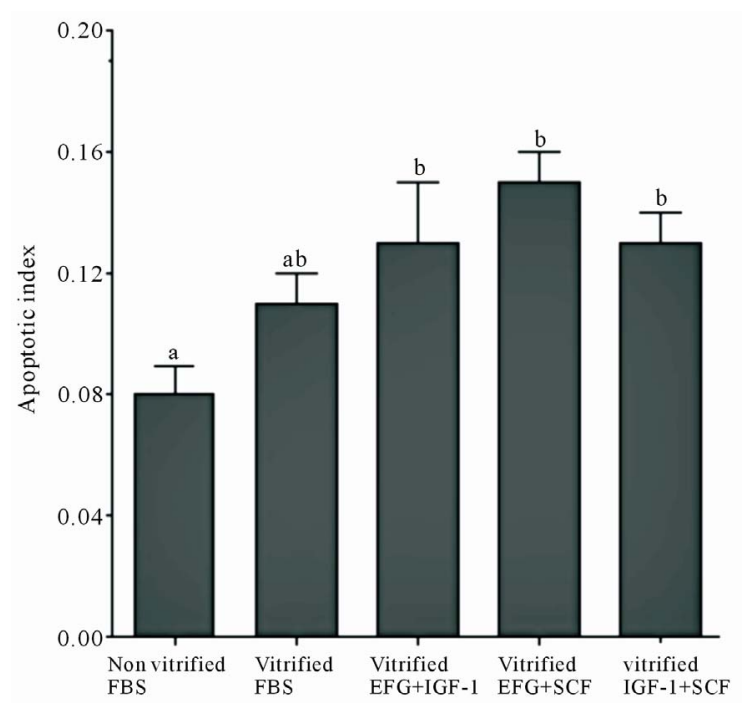

(b)

Figure 2. Variations (mean $\pm \mathrm{SEM}$ ) in the total number of cells (panel A) and DNA fragmentation index (panel B) in bovine blastocysts produced from the vitrified morulae. Morulae were derived from 3 - $10 \mathrm{~mm}$ follicles following IVM and IVF in serum-free media and IVC in serum (FBS, 4\%) or growth factor (EGF, $10 \mathrm{ng} / \mathrm{mL}$; IGF-1, $100 \mathrm{ng} / \mathrm{mL}$; SCF, $50 \mathrm{ng} / \mathrm{mL}$ ) supplemented medium. Post-thaw culturing was done in the respective medium for $4 \mathrm{~d}$. a-b on error bar indicates a significant difference $(\mathrm{P}<0.05)$.

mentation. The expression of the transcripts varied significantly in all cases, except for BIRC5 in the blastocysts derived from $3-10 \mathrm{~mm}$ follicles. The variations in the expression of these transcripts in the growth factor treated embryos were found to be within a short range of 0.5 to 1.7 fold compared to that of the embryos treated with FBS. However, from the observed profiles of gene expression, it was difficult to interpret whether the qual- ity of the growth factor treated embryos was better or inferior compared to that of the embryos treated with FBS.

The ability of an embryo to withstand freezing and thawing is a useful indicator of quality [5]. Apoptosis of embryonic cells indicates an inadequate in vitro culture environment and/or embryo freezing [25,30,31]. Altered apoptosis levels in blastocysts may lead to early embryonic death or congenital anomalies in the fetus [32]. In the current experiment, cryotolerance was assessed of the embryos that were derived from $3-10 \mathrm{~mm}$ follicles and were cultured in the presence of serum or combinations of growth factors. In the Experiment-1, the supplementation of the growth factors either individually or in combinations resulted in similar embryo development. Therefore, the combinations of growth factors were only selected for this experiment assuming that supplementation of such combinations could be beneficial over the individual growth factor supplementation for cryotolerance of embryos. The embryos were vitrified at the morula stage using the droplet vitrification method. We have shown previously that this method is efficient for preserving mouse embryos at the morula stage [33]. Following thaw and culture, the expanded/hatched blastocyst rate was significantly greater when embryos were treated with serum compared to growth factors. The results indicated better cryotolerance of the serum treated embryos compared to those treated with growth factors. Nevertheless, cryotolerance of the growth factor treated embryos was not different as was evident from the similar survival, blastocyst and expanded/hatched blastocyst rates of these embryos. There were no differences in the total number of cells and DNA fragmentation index in blastocysts derived from the vitrified morulae, indicating a similar level of apoptosis in the embryos treated with serum or growth factors.

In conclusion, embryo development was not different among the culture medium supplementations irrespective of follicle size. Nevertheless, FBS and SCF supplementations could not support satisfactory development of the embryos derived from $<3 \mathrm{~mm}$ follicles. The expression patterns of the development and apoptosis related gene transcripts in blastocysts indicated that quality of the embryos treated with growth factors was different compared to that of the embryos treated with serum. Better cryotolerance was observed when embryos were treated with serum compared to growth factors. Nevertheless, irrespective of culture medium supplementations, a similar apoptosis level was evident in blastocysts derived from the vitrified morulae.

\section{REFERENCES}

[1] Wrenzycki, C., Herrmann, D., Carnwath, J.W. and Niemann, H. (1999) Alterations in the relative abundance of 
gene transcripts in preimplantation bovine embryos cultured in medium supplemented with either serum or PVA. Molecular Reproduction Development, 53, 8-18. doi:10.1002/(SICI)1098-2795(199905)53

[2] Wrenzycki, C., Herrmann, D., Keskintepe, L., Martins, A., Sirisathien, S., Brackett, B. and Niemann, H. (2001) Effects of culture system and protein supplementation on mRNA expression in pre-implantation bovine embryos. Human Reproduction, 16, 893-901. doi:10.1093/humrep/16.5.893

[3] Rief, S., Sinowatz, F., Stojkovic, M., Einspanier, R., Wolf, E. and Prelle, K. (2002) Effects of a novel co-culture system on development, metabolism and gene expression of bovine embryos produced in vitro. Reproduction, 124, 543-556. doi:10.1530/rep.0.1240543

[4] Rizos, D., Lonergan, P., Ward, F., Duffy, P. and Boland, M.P. (2002) Consequences of bovine oocyte maturation, fertilization or early embryo development in vitro versus in vivo: Implications for blastocyst yield and blastocyst quality. Molecular Reproduction Development, 61, 234-248. doi:10.1002/mrd.1153

[5] Rizos, D., Gutiérrez-Adán, A., Pérez-Garnelo, S., De La Fuente, J., Boland, MP. and Lonergan, P. (2003) Bovine embryo culture in the presence or absence of serum: Implications for blastocyst development, cryotolerance, and messenger RNA expression. Biological Reproduction, 68, 236-243. doi:10.1095/biolreprod.102.007799

[6] Pedersen, M.E., Øzdas, ØB., Farstad, W., Tverdal, A. and Olsaker, I. (2005) Effects of bovine oviduct epithelial cells, fetal calf serum and bovine serum albumin on gene expression in single bovine embryos produced in the synthetic oviduct fluid culture system. Reproduction Fertility Development, 17, 751-757. doi:10.1071/RD05048

[7] Krisher, R.L., Lane, M. and Bavister, B.D. (1999) Developmental competence and metabolism of bovine embryos cultured in semi-defined and defined culture media. Biological Reproduction, 60, 1345-1352. doi:10.1095/biolreprod60.6.1345

[8] Block, J., Wrenzycki, C., Niemann, H., Herrmann, D. and Hansen, P.J. (2008) Effects of insulin-like growth factor-1 on cellular and molecular characteristics of bovine blastocysts produced in vitro. Molecular Reproduction Development, 75, 895-903. doi:10.1002/mrd.20826

[9] Sirisathien, S. and Brackett, B.G. (2003) TUNEL analyses of bovine blastocysts after culture with EGF and IGF-I. Molecular Reproduction Development, 65, 51-56. doi:10.1002/mrd.10263

[10] Wasielak, M. and Bogacki, M. (2007) Apoptosis inhibition by insulin-like growth factor (IGF)-I during in vitro maturation of bovine oocytes. Journal of Reproduction Development, 53, 419-426. doi:10.1262/jrd.18076

[11] Jousan, F.D. and Hansen, P.J. (2007) Insulin-like growth factor-I promotes resistance of bovine preimplantation embryos to heat shock through actions independent of its anti-apoptotic actions requiring PI3K signaling. Molecular Reproduction Development, 74, 189-196. doi:10.1002/mrd.20527

[12] Taniguchi, F., Harada, T., Nara, M., Deura, I., Mitsunari, M. and Terakawa, N. (2004) Coculture with a human granulosa cell line enhanced the development of murine preimplantation embryos via $\mathrm{SCF} / \mathrm{c}$-kit system. Journal Assistant Reproduction Genetics, 21, 223-228.

\section{doi:10.1023/B:JARG.0000040238.61586.86}

[13] Głabowski, W. (2005) The protective effect of stem cell factor (SCF) on in vitro development of preimplantation mouse embryos. Annales Academiae Medicae Stetinensis, 51, 83-93.

[14] Kurzawa, R., Glabowski, W., Baczkowski, T., Wiszniewska, B. and Marchlewicz, M. (2004) Growth factors protect in vitro cultured embryos from the consequences of oxidative stress. Zygote, 12, 231-240. doi:10.1017/S0967199404002783

[15] Głabowski, W., Kurzawa, R., Wiszniewska, B., Baczkowski, T., Marchlewicz, M. and Brelik, P. (2005) Growth factors effects on preimplantation development of mouse embryos exposed to tumor necrosis factor alpha. Reproduction Biology, 5, 83-99.

[16] Blondin, P. and Sirard, M.A. (1995) Oocyte and follicular morphology as determining characteristics for developmental competence in bovine oocytes. Molecular Reproduction Development, 41, 54-62. doi: $10.1002 / \mathrm{mrd} .1080410109$

[17] Hagemann, L.J., Beaumont, S.E., Berg, M., Donnison, M.J., Ledgard, A., Peterson, A.J., Schurmann, A. and Tervit, H.R. (1999) Development during single IVP of bovine oocytes from dissected follicles: Interactive effects of estrous cycle stage, follicle size and atresia. Molecular Reproduction Development, 53, 451-458. doi:10.1002/(SICI)1098-2795(199908)53

[18] Dhali, A., Anchamparuthy, V.M., Butler, S.P., Pearson, R.E. and Gwazdauskas, F.C. (2009) In vitro development of bovine embryos cultured with stem cell factor or insulin-like growth factor-I following IVF with semen of two bulls having different field fertility. Animal Reproduction Science, 116, 188-195. doi:10.1016/j.anireprosci.2009.02.007

[19] Dhali, A., Anchamparuthy, V.M., Butler, S.P., Pearson, R.E., Mullarky, I.K. and Gwazdauskas, F.C. (2007) Gene expression and development of mouse zygotes following droplet vitrifycation. Theriogenology, 68, 1292-1298. doi:10.1016/j.theriogenology.2007.08.030

[20] Walters, A.H., Saacke, R.G., Pearson, R.E. and Gwazdauskas, F.C. (2005) The incidence of apoptosis after IVF with morphologically abnormal bovine spermatozoa. Theriogenology, 64, 1404-1421. doi:10.1016/j.theriogenology.2005.03.011

[21] Hendriksen, P.J., Vos, P.L., Steenweg, W.N.M., Bevers, M.M. and Dielemans, S.J. (2000) Bovine follicular development and its effect on the in vitro competence of oocytes. Theriogenology, 53, 11-20. doi:10.1016/S0093-691X(99)00236-8

[22] Pavlok, A., Lucas-Hahn, A. and Niemann, H. (1992) Fertilization and developmental competence of bovine oocytes derived from different categories of antral follicles. Molecular Reproduction Development, 31, 63-67. doi:10.1002/mrd.1080310111

[23] Lonergan, P., Monaghan, P., Rizos, D., Boland, M.P. and Gordon, I. (1994) Effect of follicle size on bovine oocyte quality and developmental competence following maturation, fertilization, and culture in vitro. Molecular Reproduction Development, 37, 48-53. doi:10.1002/mrd.1080370107

[24] Niemann, H. and Wrenzycki,C. (2000) Alterations of expression of developmentally important genes in preim- 
plantation bovine embryos by in vitro culture conditions: Implications for subsequent development. Theriogenology, 53, 21-34. doi:10.1016/S0093-691X(99)00237-X

[25] Park, S.Y., Kim, E.Y., Cui, X.S., Tae, J.C., Lee, W.D., Kim, N.H., Park, S.P. and Lim, J.H. (2006) Increase in DNA fragmentation and apoptosis-related gene expression in frozen-thawed bovine blastocysts. Zygote, 14, 125-131. doi:10.1017/S0967199406003649

[26] Levy, R. (2001) Genetic regulation of preimplantation embryo survival. International Review of Cytologyev Cytol, 210, 1-37. doi:10.1016/S0074-7696(01)10002-1

[27] Boelhauve, M., Sinowatz, F., Wolf, E. and Paula-Lopes, F.F. (2005) Maturation of bovine oocytes in the presence of leptin improves development and reduces apoptosis of in vitro-produced blastocysts. Biological Reproduction, 73, 737-744. doi:10.1095/biolreprod.105.041103

[28] Knudson, C.M. and Korsmeyer, S.J. (1997) Bcl-2 and Bax function independently to regulate cell death. $\mathrm{Na}$ tional Genetics, 16, 358-363. doi:10.1038/ng0897-358

[29] Houghton, F.D. (2005) Role of gap junctions during early embryo development. Reproduction, 129, 129-135. doi:10.1530/rep.1.00277
[30] Byrne, A.T., Southgate, J., Brison, D.R. and Leese, H.J. (2002) Regulation of apoptosis in the bovine blastocyst by insulin and the insulin-like growth factor (IGF) superfamily. Molecular Reproduction Development, 62, 489-495. doi:10.1002/mrd.10153

[31] Gjorret, J.O., Knijn, H.M., Dieleman, S.J., Avery, B., Larsson, L.I. and Maddox-Hyttel, P. (2003) Chronology of apoptosis in bovine embryos produced in vivo and in vitro. Biological Reproduction, 69, 1193-1200. doi:10.1095/biolreprod.102.013243

[32] Brill, A., Torchinsky, A., Carp, H. and Toder, V. (1999) The role of apoptosis in normal and abnormal embryonic development. Journal of Assistant Reproduction Genetics, 16, 512-519. doi:10.1023/A:1020541019347

[33] Dhali, A., Anchamparuthy, V.M., Butler, S.P., Pearson, R.E., Mullarky, I.K. and Gwazdauskas, F.C. (2009) Effect of droplet vitrifycation on development competence, actin cytoskeletal integrity and gene expression in in vitro cultured mouse embryos. Theriogenology, 71, 1408-1416. doi:10.1016/j.theriogenology.2009.01.011 